\section{Kindred spirits}

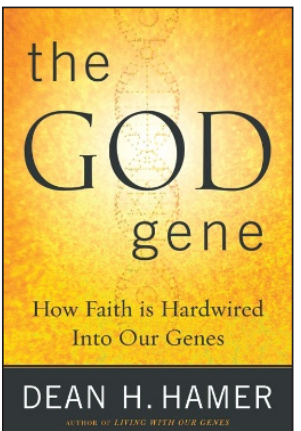

\section{The God Gene: How Faith is Hardwired Into Our Genes}

By Dean Hamer

Doubleday, 2004

256 pp. hardcover, $\$ 24.95$

ISBN 0-38550-058-0

Reviewed by Michael A Goldman

Geneticists are the first to admit that genes don't explain everything, and that the most important features of human behavior represent a complex interplay among many genes and the environment. Although we have now learned the most fundamental secrets of the human genome, and understood hundreds of mendelian genetic traits in molecular detail, we have been far less successful in our studies of the traits and genes that are vastly more important from the medical, economic, social and intellectual perspectives. We have been gun-shy when it comes to dealing with questions about how genetics interprets cognitive ability, race, personality and behavior. Once again, National Institutes of Health molecular biologist Dean Hamer fills the gap with a radical treatment of no less than the genetic basis for spirituality.

His book runs the gamut from the nature and measurement of personality traits such as spirituality to the estimation of heritability with twin studies, and on to molecular genetics. It is beautifully written and concisely stated in just over two hundred pages. In Hamer's argument, spiritual experiences and religion are nearly universal human attributes. Hamer measures spirituality on a scale of 'self-transcendence', or the ability to see beyond oneself, a concept first introduced by psychologist Robert Cloninger. He draws a sharp distinction between spirituality, which is a personality trait that some of us have to a greater or lesser extent than others, and religion or belief in a particular god, which is a culturally transmitted expression of spirituality. It might be that some of that variation in spirituality is explained by genetics, although spirituality is probably a complex trait influenced by many genes as well as the environment. If there are genetic influences, evermore-sophisticated techniques in molecular genetics should be able to tease them out. These genetic factors may have been favored during human evolution because spirituality has some positive effect on the individual's ability to reproduce. Hamer identifies one candidate gene (SLC18A2, also called VMAT2, which encodes vesicular monoamine transporter 2), which controls the transport of key neurochemicals called monoamines and may account for a fraction of the genetic vari-

Michael A. Goldman is in the Department of Biology, San Francisco State University, San Francisco, California 94132-1722, USA.

e-mail:goldman@sfsu.edu

ation in spirituality. In fact, monoamine modulation is the mechanism through which many psychoactive drugs may work and through which some of these drugs (such as psilocybin) might produce intense experiences sometimes described as spiritual or religious.

To be sure, Hamer spends plenty of time on shaky ground. Hamer admits in his introduction that the volume is misnamed; he isn't talking about genes for being a god, but rather about those that predispose us to religion-neutral spiritual beliefs, experiences and interpretations. Spirituality is not controlled by the product of a single gene but is complex, involving many genes, each making a small contribution to the phenotype, combined with a very strong environmental influence. But these days, a title like Environmental and Minor Genetic Influences on Spiritual Behavior doesn't sell books as well as one like The God Gene. Most of the complexities of inheritance are explained with care and accuracy in the book, but Hamer often falls into less-rigorous language for convenience. Unfortunately, the nonrigorous shorthand, such as "God gene", sticks, facilitating misinterpretation and enraging critics.

The most important words in Hamer's book surely are the last ones, where readers will find a take-home message. Unfortunately, the final pages seem to have a few unintentional slips. For example, "Spirituality is based in consciousness, religion in cognition. Spirituality is universal, whereas cultures have their own forms of religion. I would argue that the most important contrast is that spirituality is genetic, while religion is based on cultures, traditions, beliefs, and ideas. It is, in other words, mimetic." Well, even the most die-hard genocentrist would say that there are genetic influences that underlie a tendency toward spirituality, not that "spirituality is genetic." Hamer goes on: "The fact that spirituality has a genetic component implies that it evolved for a purpose." Although the question of why spirituality might have an evolutionary advantage is an important one, I haven't yet given in to the notion that every base pair of my DNA has some higher purpose.

Although we might like to ignore the strained leap from the laboratory bench to the Ark of the Covenant, a cover story in Time (25 October 2004) has brought the discussion to the general public. As scientists, we have, yet again, a choice between denigrating an idea as so preposterous that it does not merit even a cursory conversation, much less a read, or entering into productive discussion of the idea with people from all walks of life. Religion and spirituality pervade virtually all societies. "It's high time," says Hamer, "that people with a natural scientific bent get interested." Were it not for the fervor of Osama bin Laden and his radical cult, America's election might have been dominated by contrasting religious views about the rights of cultured embryonic cells. Perhaps we still have a great deal to learn about the chasms that divide various human constituencies from one another and that threaten to undermine the success of our species on earth. Genetics probably plays but a small part, but we could surely benefit from at least some understanding of that small part. These first preliminary studies seem to suggest that there might be good reason to view spirituality as just another part of the rich genetic and cultural variety that makes us human, and an even better reason to learn to respect and enjoy the full range of that variety. 